\title{
SAINS SEBAGAI PERLUASAN DARI ISLAM
}

\author{
Nasri \\ STIT Palapa Nusantara Lombok NTB \\ nasriazkia@gmail.com
}

\begin{abstract}
Islam is a religion based on submission (Taslim) towards the will of God Almighty, Allah SWT and based on the knowledge of His oneness. Islam is the last religion. The prophet of Islam is Khatam Al-Anbiya (Closing of the Prophets) and fourteen centuries of human history have recognized the validity of Islam as the last religion. The relationship between the Qur'an and science is a priori surprising, especially if it becomes a barmony and not a contradiction. The confrontation between religious books and scullary ideas proclaimed by science, perhaps in the eyes of people is now a paradox.
\end{abstract}

Keywords: Science, Religion

\begin{abstract}
Abstrak : Islam adalah agama yang berdasarkan pada kepasrahan (Taslim) terhadap kehendak Tuhan Yang Maha Esa, Allah SWT dan berdasarkan pada pengetahuan tentang keesaan-Nya.Islam adalah agama terakhir. Nabi islam adalah Khatam AlAnbiya (Penutup Para Nabi) dan empat belas abad sejarah manusia telah mengakui validitas islam sebagai agama terakhir. Hubungan antara Al-Qur'an dan sains secara a priori mengejutkan, terutama jika menjadi sebuah harmoni dan bukan pertentangan. Konfrontasi antara buku agama dan gagasan-gagasan sekuler yang diproklamasikan sains, mungkin dimata orang-orang sekarang merupakan sebuah paradoks.
\end{abstract}

Kata Kunci : Sains, Agama

\section{PENDAHULUAN}

Salah satu tema yang terus-menerus muncul dalam keilmuan islam tradisional adalah klasifikasi dan deskripsi ilmu-ilmu (al-ulum). ${ }^{1}$ Islam adalah agama yang berdasarkan pada kepasrahan (Taslim) terhadap kehendak Tuhan Yang Maha Esa,Allah SWT dan berdasarkan pada pengetahuan tentang keesaan-Nya. Islam adalah agama terakhir. Nabi islam adalah Khatam Al-Anbiya (Penutup Para Nabi) dan empat belas abad sejarah manusia telah mengakui validitas islam sebagai agama

1 Osman Bakar, Hierarki Ilmu, Terjemahan Dari Classification Of Knowledge In Islam: A Study In Islam Philosophies Of Science, Penerjemah Purwanto (Bandung: Mizan, 1997). Hlm.17.

Islamika : Jurnal Keislaman dan Ilmu Pendidikan

Volume 1, Nomor 2, Juli 2019; 102-115

https:// ejournal.stitpn.ac.id/index.php/islamika 
terakhir. ${ }^{2} J a d i$, semua orang di dunia sudah mengakui bahwa agama islam adalah agama terakhir di muka bumi ini, dan juga sudah diakui oleh ilmuan-ilmuan barat bahwa kitab suci al-qur'an adalah kitab terbaik dari segala kitab agama di muka bumi ini. Terbukti dengan banyak temuan-temuan berdasarkan isi dari al-qur'an itu sendiri.

Hubungan antara Al-Qur'an dan sains secara a priori mengejutkan, terutama jika menjadi sebuah harmoni dan bukan pertentangan. Konfrontasi antara buku agama dan gagasan-gagasan sekuler yang diproklamasikan sains, mungkin di mata orangorang sekarang merupakan sebuah paradoks. Sebagian besar ilmuan zaman ini, tentu saja dengan sedikit pengecualian, sibuk dengan teori-teori materalis, dan bersikap acuh tak acuh atau jijik terhadap pertanyaan-pertanyaan keagamaan yang sering mereka anggap hanya ada dalam dongeng, lagi pula di barat, ketika sains dan agama didiskusikan, begitu mudahnya orang-orang menyebutkan agama yahudi dan Kristen di antara agama-agama yang diacu, namun sulit menyebut islam. Demikian banyak pendapat keliru yang didasarkan pada gambaran tidak tepat tentang islam, sehingga saat ini sangat sulit membangun sebuah gagasan tepat tentang islam yang sesungguhnya. ${ }^{3}$

Al-Qur'an adalah terjemahan azali kepada kitab yang maha besar bagi sekalian makhluk ini. Terjemahan abadi kepada seluruh bahasanya yang berbagai-bagai dan membaca (melihat) tanda-tanda kekuasaan Allah yang berbentuk kejadian. ${ }^{4}$ Al-Qur'an sebagai kitab suci ummat islam perlu difungsikan dalam kehidupan sehari-hari, baik dalam bersikap, bertindak maupun bertingkah laku. Untuk memfungsikan al-qur'an tersebut, kaum muslimin dituntut untuk menggali dan memahami sungguh-sungguh apa yang menjadi isi al-qur'an serta mengamalkannya dalam kehidupan sehari-hari. Melihat fungsi dari al-qur'an itu banyak sekali seperti sebagai pedoman hidup, sebagai hukum, sebagai pengukuh/penguat, sebagai sumber hukum, sebagai sumber ilmu dan peradaban, sebagai al-furqan (pemisah), sebagai obat, sebagai nur (cahaya), dll. ${ }^{5}$

${ }^{2}$ Sayyed Hossein Nasr, Menjelajah Dunia Modern, Terjemahan Dari A Young Muslim's Guide To The Modern World, (Bandung: Mizan, 1994), Penerjemah Hasti Tarekat, Hlm.15-17.

${ }^{3}$ Maurica Bucaille, Sains Dalam Al-Qur'an Dan Injil, Diterjemahkan Oleh Yudi Santoso Dan Ahmad Mustofa (Yogyakarta:Balqist, 2011), Hlm.147.

4Josef Sou'yb. 1996. Agama-Agama Besar Didunia. PT Al Husna Zikra.

${ }_{5}^{5}$ Mundzirin Yusuf Dan H. Sanuri ,Islam Dan Iptek, (Jakarta: PT RajaGrafindo Persada, 1998). Hlm.1-13. 
Banyak firman Allah SWT dalam ayat-ayat al-qur'an ditujukan kepada orangorang yang beriman dan bertaqwa, kepada orang-orang yang berakal, berfikir dan berilmu. ${ }^{6}$ Akan tapi sedikit orang yang mengetahui dan mengamalkannya. Kebanyakan al-qur'an dijadikan sebagai pajangan dikamar atau dirumah, dibaca ketika ada acaraacara resmi, dijadikan sebagai kaligrafi, dll. Sehingga apa yang terjadi, banyak para masyarakat kita mengatakan bahwa al-qur'an itu tidak sesuai dengan zaman, kenapa tidak dijelaskan ilmu ini dalam al-qur'an. Itu semua adalah karena kita tidak pernah menggali secara benar isi al-qur'an tersebut.

Berbeda dengan para ulama-ulama kita terdahulu, mereka memaknakan alqur'an sebagai sumber kehidupan, artinya bahwa dalam al-qur'an tentang kehidupan sudah jelaskan, tentang ilmu, dll. Sehingga kita mengenal Ibnu Sina sebagai bapak kedokteran dan juga ahli dalam agama, Ibnu Rusyd,Ibnu Kaldum, Khwarizmi, dll. Ini menunjukkan bahwa cara pandang kita dalam memahami al-qur'an berbeda, kita hanya sebatas membacanya tetapi mereka selain membaca juga sebagai sumber inspirasi dalam kehidupan, sehingga kita kenal ada namanya ilmu falak, ilmu fisika, matematika, filsafat, faraait, dll. Jadi semua ilmu yang ada di dunia ini sumbernya dari al-qur'an itu sendiri.

Di dalam al-qur'an menggunakan kata 'ilm dalam berbagai bentuk dan artinya sebanyak 854 kali. Antara lain sebagai "proses pencapaian pengetahuan dan objek pengetahuan" (QS 2:31-32). Sementara itu ahli keislaman berpendapat bahwa ilmu dalam Al-Qur'an mencakup segala macam ilmu pengetahuan yang berguna bagi manusia dalam kehidupannya. Baik masa kini maupun masa depan;fisika atau metafisika. ${ }^{7}$ dapat kita ketahui, bahwa dalam al-qur'an kata ilmu sangat beragam artinya sehingga muncullah beberapa ilmu.

Setelah kita ketahui, bahwa semua yang ada di dunia sudah diterangkan dalam al-qur'an, baik kehidupan di dunia dan akhirat, dan yang lebih penting adalah ilmu. Karena dengan ilmu kita bisa mengenal sang pencipta. Untuk itu seperti apa ilmu (sains) dalam al qur-an itu, ilmu apa saja yang terdapat dalam al-qur'an itu. Pada kesempatan ini penulis hanya memaparkan satu dari sekian banyak ilmu dalam al-

${ }^{6}$ Bayong Tiasyono HK, Manusia Dalam Alam Semesta (Bandung: ITB, 2012). Hlm.1. Hlm.,92.

7 M. Quraish Shihab, Membumikan Al-Qur'an (Bandung: Mizan, Cetakan Ke-3, 2009), 
qur'an yaitu matematika. Karena, matematika adalah salah satu ilmu yang penting dalam kehidupan, baik dalam jual beli, astronomi, zakat, paraid, dll. Tanpa kita mengenal ilmu matematika maka kita tidak akan tahu bagaimana cara membagi yang benar ilmu tersebut (faraid, zakat).

\section{Tokoh Islam dalam Sains}

Berbicara masalah tokoh islam dalam Sains sangat banyak sekali, tetapi di sini saya hanya memaparkan satu saja, karena tokoh yang satu ini sangat berperan dalam perkembangan matematika dan juga temuannya sampai sekarang bisa kita pelajari, adapun tokoh tersebut adalah Khwarizmi.

Khwarizmi lahir sebelum tahun $800 \mathrm{M}$ dan meninggal setelah tahun $847 \mathrm{M}$. Nama lengkapnya adalah Abu Abdullah Muhammad Ibn Musa. Ia dikenal dengan sebutan al-khwarizmi karena berasal dari khawarizmi, sebuah daerah di timur laut kaspia. ${ }^{8}$ Ada juga berpendapat bahwa nama lengkap khawarimi adalah Abu Ja'far Muhammad B. Musa Al-Khawarizmi, dia lahir di Khawarizm ,Persia, pada tahun $780 .{ }^{9}$

Khawarizmi di perkirakan hidup di pinggiran Bagdad pada masa khalifah AlMa'mun (813-833 m) dari dinasti Abasiyyah. Khalifah Ma'mun menjadi sahabat karibnya yang menjadikan khawarizmi sebagai anggota baitul hikmah di Bagdad, yakni sebuah lembaga penelitian ilmu pengetahuan yang didirikan oleh khalifah Harun Ar-Rasyid. Baitul Hikmah memiliki berbagai keunggulan yang mashur di dunia islam.

Al-khawarizmi dalam bidang astronomi dan aljbar didedikasikan kepada khalifah Al-Ma'mun. sedangkan khalifah Al-Ma'mun sendiri banyak memberikan penghargaan kepada Khawarizmi. Penulis sejarah matematika kenamaan, George Sarton, mengungkapkan bahwa Al-Khawarizmi termasuk salah seorang ilmuan muslim terbesar dan terbaik pada masanya. Sarton menggolongkan periode antara abad ke 4-5 sebagai abad Khawarizmi, karena ia adalah ahli matematikawan terbesar pada masanya.

${ }^{8}$ M. Yusuf Abdurrahman, Cara-Cara Belajar Ilmuan Muslim Pencetus Sains-Sains Canggib Modern, (Jogjakarta: Diva Pess, 2013). Hlm.92. Hlm.110.

9 Husain Heriyanto, Menggali Nalar Saintifik Peradaban Islam (Bandung: Mizan, 2011). 
Smith dan Karpinski menggambarkan pribadi Al-Khawarizmi sebagai tokoh terbesar pada masa keemasan Bagdad, setelah seorang penulis muslim menggabungkan ilmu matematika klasik barat dan timur, lalu mengklafiskasikan, hingga akhirnya membangkitkan kesadaran daratan Eropa.

Khawarizmi termasuk perintis ilmu pasti muslim, bukunya Aljabar WalMuqabala (pengetahuan kembali dan perbandingan) dalam terjemahan latinya merupakan ransangan kepada Ilmu pasti Eropa abad pertengahan. Dari sanalah asalya istilah Algebradi dalam bahasa-bahasa Eropa. Dan di wafat pada tahun 266 h/840 M di Bagdad. ${ }^{10}$

\section{Awal munculnya matematika dalam Islam}

Perkembangan sains matemaika dalam islam, sebenarnya dimulai sejak diturunkannya al-qur'an sebagai kitab suci. Di dalamnya banyak terdapat anjuran untuk mempelajari dan merenungkan angka untuk kepentingan sehari-hari misalnya pembagian harta warisan. Sementara itu, kajian matematika secara ilmiah dimulai sejak umat islam bersentuhan dengan beberapa karya bidang matematika yang dihasilkan oleh peradaban lain seperti India dan Yunani.

Seiring dengan meluasnya kekuasaan islam, banyak wilayah yang kaya dengan tradisi keilmuan peradaban pra islam berada di bawah kekuasaan islam. Di antara daerah itu adalah Alexsandria yang ditaklukkan ummat islam pada tahun 641 di daerah ini merupakan pusat matematika dunia saat itu. Selain itu, Bagdad sebagai pusat pemerintahan Abbasiyyah di jadikan sebagai pusat ilmu pengetahuan, sehingga di kota inilah aktifitas seperti tukar-menukar ilmu antar ilmuan melalui karya dan program penerjemahan dalam berbagai bidang termasuk matematika dilakukan. Pada tahun 766 misalnya karya astronomi dan matematika berjudul sindhind yang berasal dari India dibawa ke Bagdad. Secara umum karya tersebut disamakan dengan Brahmasphuta Siddhanta, meski sudah menjadi Surya Sidhanta. Pada tahun 775

10 S.I. Poeradisastra, Sumbangan Islam Kepada Ilmu Dan Peradaban Modern (Jakarta: Komonitas Bamboo,2008). Hlm.33. 
Siddhanta diterjemahkan kedalam bahasa arab, disusul berikutnya pada tahun 780 karya Ptolemy berjudul Tetrabiblos diterjemahkan ke dalam bahasa arab. ${ }^{11}$

Perkembangan dalam ilmu dalam islam dikarenakan juga karena selalu para pemimpin pada saat itu selalu mementingkan ilmu pengetahuan, kita bisa lihat bagaimana upaya dalam memahami ilmu-ilmu dari tulisan non muslim. Mereka melakukan penerjemahan dan secara langsung mengundang ahli dalam masalah ini. Ini adalah salah satu bentuk awal dari kemajuan dalam ilmu khususnya dalam matematika, sehingga para ilmuan muslim bisa memahami dan mempelajari matematika dari buku-buku yang diterjemahkan kemudian memadukan dengan alqur'an dan hadis. Sehingga muncullah penemuan-penemuan baru.

Bangsa Arab mewarisi dan mengembangkan beberapa sistem penghitungan aritmatika. Penghitungan dengan jari digunakan oleh orang Arab sebelum datangnya islam. Penghitungan ini terkenal dengan Hisab Al-Jummal, yang mengacu pada penggunaan urutan huruf alfabetik untuk menunjukkan angka. karena sistem ini bersifat mental, maka penambahan dan pengurangan cukup sederhana sementara berbagai macam skema yang digunakan untuk perkalian, pembagian, dan rasio, yang merupakan penghitungan rumit, sangat sulit dilakukan. Itulah sebabnya menghitung dengan jari mulai hilang sejak diperkenalkan artimetika india, yaitu sebuah dasar untuk rumus perhitungan dan kalkulasi. ${ }^{12}$

Penghitungan atau matematika ternyata sebenarnya sudah lama berkembang sebelum datangnya islam, tetapi dalam aplikasinya sangat sulit sekali sehingga sedikit orang yang paham. Seandainya seperti itu matematika sekarang mungkin pembelajaran matematika akan menjadi musuh bagi semua murid, tetapi dengan datangnya para cendikiawan muslim matematika bisa disederhanakan dan bisa dipahami oleh semua orang.

Barat dalam bidang matematika, penerimaan angka arab di Eropa dilakukan secara kronologis. Waktu itu Eropa barat menggunakan angka-angka romawi yang tidak praktis, yang benar-benar menambah kesulitan sebagian besar kerja matematika dan menghambat penelitian dalam teori matematika secara serius. Pengenalan angka-

11 Muqowin, Genealogi Intlektual Saintis Muslim (Jakarta: Kementrian Agama RI, 2012). Hlm.133.

${ }^{12}$ Ibid. Hlm.135. 
angka secara efektif terjadi setelah diterbitkan Leber Abaci, karya Leonardo Fibonacci dari Pisa pada tahun 1202.Dalam buku itu, penulisannya menunjukkan bagaimana "sepuluh tanda" memungkinkan penyederhanaan dan perluasan kerja-kerja aritmatika. $^{13}$

Perkembangan di barat dalam hal sains di sebabkan oleh timur, karena dalam serangan yang dilakukan oleh kerajaan mongol tersebut menyebabkan banyak kitabkitab yang diambil oleh barat, sehingga dengan melakukan penerjemahaan, kemudian dia mengaku bahwa itu adalah karyanya sendiri. Sedangkan islam ditutupi dari semua yang telah dilakukannya.

\section{Matematika sebelum datangnya Islam}

\section{Matematika bangsa Mesir}

Menurut Boyer, Mesir kuno adalah yang pertama mengenal bilangan. Bangsa ini telah menggunakan penghitungan sistem bilangan desimal (puluhan) yang didasarkan pada jumlah jari di tangan manusia yaitu sepuluh jari. Prinsip sistem desimal adalah manusia mempunyai sepuluh jari di tangannya dan apabila ia ingin menghitung maka sepuluh jari itu akan digunakan sebagai alat hitung. System inilah yang digunakan dalam kehidupan sehari-hari sekarang.

Angka-angka dalam sistem bilangan Bangsa Mesir kuno ditulis berdasarkan huruf Hieroglyph yang mulai digunakan sejak 3500 SM hurup Hieroglpy terdiri dari gambar-gambar kecil yang menyatakan sebuah kata. Dalam sistem bilangan Bangsa Mesir kuno, operasi-operasi aljabar pada bilangan seperti penjumlahan, pengurangan, perkalian, dan pembagian dapat juga dilakukan. Operasi penambahan, misalnya dapat dilakukan dengan mudah yang hanya menambah satu simbol, namun mengganti sepuluh salinan dari satu simbol dengan satu simbol tunggul dari nilai yang lebih tinggi berikutnya. Dengan cara yang sama operasi-operasi aljabar lainnya dapat dilakukan. Pengetahuan matematika Mesir kuno dapat diketahui melalui beberapa dokumen, yaitu Lontar Ahmes, Lontar Moskow, Lontar Rhind, Lontar Kahun, dan Lontar Berlin.

${ }^{13}$ Budi Handrianto, IslamisasiSains(Jakarta Timur: Pustaka Al-Kautsar, 2010). Hlm.113-114 


\section{Matematika Bangsa Babilonia}

Kawasan sungai Tigris dan Eufrat merupakan tempat berdirinya peradaban pertama di dunia, yaitu kerajaan Babylonia.Di kawasan tersebut telah ditemukan catatan matematika dan astronomi pertama di dunia yang ditulis dengan tulisan mismari antara tahun 2300 dan 1600 SM.

Berkaitan dengan perhitungan dan penulisan bilangan, bangsa Babylonia telah menggunakan sistem desimal dan sistem enam puluhan. Sistem enam puluhan menggunakan bilangan 60 sebagai basis. Penggunaan bilangan 60 sebagai basis didasarkan pada pertimbangan bahwa satu jam terdiri enam puluh menit dan enam puluh menit terdiri dari 60 detik. Sampai saat ini belum ditemukan contoh-contoh bilangan yang digunakan bangsa Babylonia. Para peneliti berpendapat bahwa bangsa Babylonia memiliki peran besar dalam mengajar bangsa india tentang cara penggunaan sistem bilangan.

\section{Matematika Bangsa China}

Bangsa China dianggap berjasa dalam pembuatan nilai untuk setiap angka atau apa yang disebut dengan digit (kedudukan). Orang China mengenal angka-angka satuan seperti $1,2,3, \ldots, 9$. Nilai bilangan-bilangan dibedakan dengan menggunakan huruf abjad yang berkaitan dengan digitnya. Misalnya angka tiga puluh ditulis degan gabungan angka 3 dengan huruf pertama kata puluhan yaitu 30 menjadi 3P.dengan cara yang sama 300 ditulis $3 \mathrm{R}$ dan seterusnya.

Dengan demikian, bangsa China telah membantu bangsa India dalam penemuan angka-angka yang digunakan sekarang. Hal ini menunjukkan adanya keterpaduan yang baik antara peradaban kuno seperti Mesir kuno, Yunani, Romawi, China, dan India maupun peradaban modern seperti islam dan barat.

Di antara tokoh matematikawan dari China yang hidup sebelum tahun masehi adalah Chang Ts'ang, Lo Hsia Hung, Keng Shou-Ch'ang. Sementara itu, matematikawan yang hidup sesudah masehi antara lain adalah Liu Hsin, Hsu Yuen, Sun Tzu, Wang Fan, Liu Hui, Hsia-Hou Yang, Chen-Luan, Chang Ch’iu-Chhing, dan Wang Hsiao-T'ung. Mencermati tokoh-tokoh matematika tersebut menunjukkan bahwa tradisi matematika di China termasuk lebih baik dibandingkan tradisi Romawi sebagaimana terlihat di bawah. 


\section{Matematika Bangsa Yunani}

Matematika di Yunani berkembang antara tahun 600 SM sampai 600 M yang berkembang mulai dari wilayah Ionia sampai Italia, Athena, Alexsandria dan belahan bumi lainnya. Rentang waktu dan tempat tersebut menghasilkan banyak perubahan dalam hal kedalaman dan luasnya kegiatan matematika. Para tokoh matematikawan yang lahir di tradisi matematika yunani antara lain Pythagoras, Hippias dan Elis, Philolaus dari Tarentum, Archytas dari Tarentum, Demucritus (Dimuqratis) dari Abdera, dll. Berdasarkan perjalanan hidup matematikawan di atas, tampak bahwa mereka tidak hanya menguasai satu disiplin ilmu, namun banyak. Hal ini dapat dimaklumi mengingat adanya kaitan erat antara disiplin ilmu satu dengan yang lain, misalnya sains matematika, astrinimi, geografi, dan mekanika. Hal serupa juga tampak dari saintis muslim yang cenderung bercorak Ensiklopedis dalam penguasaan disiplin ilmu, sehingga tidak mudah mengelompokkan seorang ilmuan muslim hanya satu disiplin ilmu saja.

\section{Matematika Bangsa Romawi}

Metode penulisan bilangan Bangsa Romawi disebut metode limaan-puluhan yang itu menggunakan bilangan lima dan sepuluh sebagai basis disertai dengan operasi penjumlahan dan pengurangan. Dalam metode Romawi ini angka dinotasikan dengan jari tangan yaitu satu garis vertikal. Notasi angka 1 atau garis vertikal itu diulang tulisannya dua dan tiga kali untuk menotasikan angka dua dan angka tiga berturut-turut. Misalnya angka delapan Romawi adalah delapan garis vertikal yang ditulis sejajar. Angka lima dinotasikan dengan satu tangan yang isinya lima jari tetapi karena jempol berbeda bentuknya dengan keempat jari lainnya dalam tangan maka satu tangan digambar dengan $\mathrm{v}$ yang demikian menjadi notasi angka lima. Dan seterusnya.

Di antara matematikawan dari romawi adalah Xenarchos, Balbus, Hygisnus, Apuleus, Anthemios, dan Eutocios. Dibandingkan dengan tradisi matematika yunani, matematika romawi kurang berkembang. Di antara matematikawan tersebut sebagian besar juga sebagai seorang astrolog. 


\section{Matematika Bangsa India}

Matematika di India juga tidak kalah pesatnya dengan peradaban lain, adapun bentuk kemajuannya yaitu sudah mengetahui huruf sepeti huruf arab, kemudian dengan perkembangan zaman maka huruf itu seperti yang kita kenal sekarang yaitu 1,..9. yang paling menarik juga yaitu sudah mengenal angka nol, akan tetapi didalamya dikasih titik, sebelum mengenal angka nol ada tanda khusus untuk membedakan puluhan dengan ratusan. Tetapi, setelah mengenal angka nol sudah tidak terpakai lagi simbol itu. Bisa kemungkinan candi-candi yang kita lihat di sekitar kita khususnya di Indonesia pengaruh dari peradaban india juga pada saati itu. Adapaun tokoh dalam matematika Inda yaitu Aryabhata dan Brahmagupta, selain beberapa ilmuan tersebut, di India juga ada karya bernama siddahanta. ${ }^{14}$

Merujuk dari kemajuan dan perkembangan matematika pada zaman sebelum islam, maka dapat kita simpulkan bahwa perkembangan ilmu begitu pesat dan begitu vital sekali untuk menyongsong perubahan dalam suatu Negara. Terkait dengan matematika begitu banyak versi sehingga kita pada zaman sekarang bisa menghitung dengan berbagai cara juga, semuanya itu benar karena begitu banyak ragam dalam ilmu matematika tersebut. Terkait dengan islam, dalam ilmuan muslim mengambil semua mulai dari Yunani sampai India, kemudian mengembangkan dan mengkomparasikan dengan zaman, mana yang lebih mudah diterima oleh masyarakat.

Di dalam al-qur'an juga banyak menyinggung tentang penghitungan, salah satunya yaiatu tentang ilmu waris, zakat. Tujuh lapis langit dan bumi.Ini menunjukkan bahwa dalam al-qur'an sudah ada tentang ilmu matematika tersebut. Ilmu-ilmu yang dibahas dalam matematika

Dalam ilmu matematika mempelajari tentang ukuran-ukuran dan mencakup empat macam ilmu. Pertama, Ilmu ukur (geometri).Ilmu membahas tentang ukuran, baik yang tersambung, seperti garis dan bidang, maupun yang terpisah, seperti bilangan-bilangan. Di antara cabang ilmu geometri adalah geometri yang dikhususkan untuk mengukur bentuk-bentuk bulat dan kerucut. Ibnu kaldum menjelaskan faedah dan manfaat yang bisa diambil dari ilmu geometri. Ia menjelaskan faedah-faedahnya

\footnotetext{
${ }^{14}$ Ibid.131.
} 
bagi orang yang mempelajari dan bagi umat manusia pada umumnya. Ilmu geometri bisa membuat akal orang yang mempelajarinya menjadi tenang dan pemikirannya menjadi semakin lurus. Sebab, semua bukti yang dihadirkan oleh ilmu ini sangat jelas dan teratur, runut, hampir tidak pernah keliru. Menerapkan ilmu ini bisa meminimalisasi kesalahan pada pemikiran.

Kedua, Ilmu bilangan. Cabang ilmu bilangan adalah aritmatika yang dipergunakan untuk mengetahui bilangan-bilangan khusus. Cabang ilmu-ilmu bilangan lainnya adalah ilmu (sina'ah) alhisab, yakni ilmu praktis dalam menghitung bilangan melalui penambahan dan pembagian, yang meliputi penggabungan, pengurangan, pengkalian, ratio, proporsi, dan seterusnya. Ketiga, Ilmu musik.

Keempat, Ilmu astronomi (Al-Hai'ad).Ilmu ini meneliti gerakan-gerakan bintang yang tetap, bergerak, dan berubah-ubah, selain juga menelaah mekanisme gerakangerakan tersebut di dalam galaksi-galaksi yang mengintarinya. Ilmu ini juga menjelaskan bahwa poros bumi itu berbeda dengan poros galaksi dengan adanya gerakan maju dan mundurnya. ilmu astronomi ini juga dikenal dengan ilmu falak. ${ }^{15}$

Melihat dari cabang ilmu matematika itu, jika kita amati dalam al-qur'an bahwa semuanya sudah dijelaskan seperti bintang, bumi dan langit. Sehingga semakin jelas bahwa ilmu-ilmu itu semuanya dari al-quran dan perluasan dari pemahaman umat islam yang memahaminya secara seksama. Selanjutnya kita melihat bagaimana bentuk sumbangan ilmuan muslim terkait dengan ilmu matematika dalam peradaban di dunia ini khususnya dalam perkembangan ilmu islam. Karena ini sangat penting sekali kita ketahui agar kita sebagai muslim mengetahui kecerdasan ilmuan muslim dalam ilmu matematika khususnya.

\section{Sumbangan ilmuan muslim dalam matematika}

Al-khwarizmi membina aljabar yang telah dimulai oleh Dipohantes (250 PraMasehi) dari Yunani.Tulisan Diophantes yang masih kabur dibersihkan dari kesalahan-kesalahan dan selanjutnya dikembangkan. Oleh sebabnya Khwarizmi

${ }^{15}$ Said Ismail Ali, Pelopor Pendidikan Islam Paling Berpengarub, Terjemahan Dari A'lam Tarbiyyah Fi Al-Hadharah Al-Islamiyyah, Penerjemah Muhammad Zainal Arifin (Jakarta: Al-Kautsar, 2010). Hlm. 104105. 
disebut bapak aljabar. Selain itu Khwarizmi telah memberikan beberapa rumus ilmu ukur, di antaranya mengenai segi tiga dan sistem persepuluhan. ${ }^{16}$

Pertama,dia memperkenalkan perhitungan sistem desimal (persepuluh) yang menggantikan sistem segi tiga desimal itu sampai sekarang masih tersisa dalam perhitungan waktu: jam (60 menit), menit (60 detik), dan perhitungan busur derajat.

Kedua, Al-khwarizmi meletakkan dasar-dasar ilmu hitung dan aljabar, untuk pertama kalinya al-khwarizmi menggunakan simbol-simbol dan variabel-variabel, mendahului sarjana-sarjana Eropa, dan penggunaan simbol-simbol itulah yang mendorong kemajuan pesat matematika.

Ketiga,dia menerapkan bilangan nol (Shifr) untuk pertama kalinya dalam penghitungan sistem desimal (Aritmatika) dan aljabar. Kata arab shifr, yang berarti nol, masuk ke Eropa menjadi Cipher, Chiffre, dan Zero. Aplikasi bilangan tersebut merupakan sumbangan penting bagi kemajuan matematika modern sedemikian rupa sehingga tanpa angka nol itu banyak operasi dari persoalan matematika sekarang yang tidak dapat diterselesaikan.

Keempat,dia menemukan nilai $\pi$ (Phi) yang menyatakan perbandingan keliling sebuah lingkaran terhadap garis tengahnya, yaitu sebesar 22/7=3,1428571 (bilangan dengan $\pi$ modern yang bernilai $=3,1415926)$. Khwarizmi menemukan bahwa perbandingan keliling terhadap garis tengah lingkaran bernilai tetap (disebut konstanta) tanpa tergantung pada ukuran lingkarannya. Penemuan konstatanta $\pi$ (Phi) tersebut sangat berguna untuk penghitungan-penghitungan yang berkaitan dengan lingkaran dan bola seperti luas dan volume.

Kelima, Khwarizmi berjasa menyusun daftar logaritma. Istilah logaritma(Algoritma) berasal dari nama Al-khwarizmi sendiri. Istilah algoritma sendiri sekarang digunakan dalam pengertian sebagai suatu tata cara sistematis untuk menemukan jawaban dari sebuah soal di mana tiap langkah harus jelas letaknya.

Keenam, Al-khwarizmi juga menemukan metode aljabarik untuk menghitung tinggi segi tiga. Dengan metode tersebut, tinggi sembarang segitiga dapat dihitung dengan metode penjabaran sisi-sisi segitiga yang diketahui.

${ }^{16}$ S.i...hlm.34. 
Ketujuh, Al-khwarizmi merumuskan penyelesaian persamaan kuadrat dengan memperkenalkan konsep variabel, parameter, akar kuadrat, dan bersama ilmuan muslim lainnya memecahkan persamaan kuadrat $a x^{2}+b x+c=0$ dengan rumus sekarang yang dikenal rumus $a b c: x_{1,2}=\left[-b \pm \sqrt{ }\left(b^{2}-4 a c\right)\right] / 2 a . x$ disebut sebagai akar-akar persamaan kuadrat (variabel yang dicari); sedangkan a,b, dan c disebut sebagai parameter.

Selain dengan rumus yang terkenal itu, Al-khwarizmi juga memperkenalkan metode "pelengkapan kuadrat" untuk menyelesaikan persamaan kuadrat dan kubik, suatu metode yang sampai sekarang dipelajari oleh siswa SMA. ${ }^{17}$ Dapat di simpulkan bahwa aljabar adalah penyempurnaan atau pengembangan dari ilmu yang sudah ada.

\section{KESIMPULAN}

Khawarizmi adalah tokoh yang sangat berperan penting dalam peradaban islam dalam hal matematika, karena dengan karyanya yang sangat fenomenal itu namanya terus harum dan diakui pula oleh ilmuan barat. Perkembangan matematika sebenarnya sudah ada sebelum ada agama islam. Akan tetapi dalam pengaplikasiannya sangat sulit dipahami oleh masyarakatnya. Bagian dari matematika ternyata banyak, sehingga kita dapat mengenalnya itu ilmu hitung, musyrik, dll. Dalam temuannya alkhwarizmi itu banyak sekali, mulai dari desimal sampai persamaan kuadrat.

\section{DAFTAR PUSTAKA}

Bayong Tiasyono HK, Manusia Dalam Alam Semesta, Bandung: ITB, 2012. Budi Handrianto, IslamisasiSains, Jakarta Timur: Pustaka Al-Kautsar, 2010. Husain Heriyanto, Menggali Nalar Saintifik Peradaban Islam, Bandung: Mizan, 2011. Josef Sou'yb. Agama-Agama Besar Didunia. PT Al Husna Zikra, 1996.

M. Quraish Shihab, Membumikan Al-Qur'an, Bandung: Mizan, Cetakan Ke-3, 2009.

M. Yusuf Abdurrabman, Cara-Cara Belajar Ilmuan Muslim Pencetus Sain-Sains Canggih Modern, Jogjakarta: Diva Pess, 2013.

Maurica Bucaille, Sains Dalam Al-Qur'an Dan Injil, Diterjemahkan Oleh Yudi Santoso Dan Ahmad Mustofa, Yogyakarta:Balqist, 2011.

${ }^{17}$ Hysain..hlm.,113-114. 
Mundzirin Yusuf Dan H. Sanuri ,Islam Dan Iptek, Jakarta: PT RajaGrafindo Persada, 1998.

Muqowin, Genealogi Intlektual Saintis Muslim, Jakarta: Kementrian Agama RI, 2012.

Osman Bakar, Hierarki Ilmu, Terjemahan Dari Classification Of Knowledge In Islam: A Study In Islam Philosophies Of Science, Penerjemah Purwanto, Bandung: Mizan, 1997.

S.I. Poeradisastra, Sumbangan Islam Kepada Ilmu Dan Peradaban Modern, Jakarta: Komonitas Bambu, 2008.

Said Ismail Ali, Pelopor Pendidikan Islam Paling Berpengarub, Terjemahan Dari A'lam Tarbiyyah Fi Al-Hadharah Al-Islamiyyah, Penerjemah Mubammad Zainal Arifin, Jakarta: Al-Kautsar, 2010.

Sayyed Hossein Nasr, Menjelajah Dunia Modern, Terjemahan Dari A Young Muslim's Guide To The Modern World, Penerjemah Hasti Tarekat, Bandung: Mizan, 1994. 